\title{
An Exploration of the Spoken English Teaching in Beijing English Training Schools
}

\author{
Weihong Li \\ Foreign Language Department, Beijing Information Science \& Technology University, Beijing, China \\ Email: bellevive@yahoo.com.cn \\ Xuedong Shi \\ Foreign Language Department, Beijing Information Science \& Technology University, Beijing, China \\ Email: wlnos@yahoo.com.cn
}

\begin{abstract}
This study aims to explore the spoken English teaching methods and techniques in Beijing English Training Schools, such as, New Oriental School. Through the date analysis and discussion to the interviews to 8 spoken English teachers and 100 questionnaires to the spoken English class students in New Oriental School, one of the Beijing English Training Schools, demonstrate the characteristics of the spoken English teaching methods and techniques in Beijing English Training Schools. The findings of this exploration help other spoken English teachers both in public schools and English training schools to improve their spoken English teaching in China.
\end{abstract}

Index Terms - spoken English teaching, Beijing English training schools, teaching methods and techniques

\section{INTRODUCTION}

With increasing globalization, spoken English teaching is playing an increasingly important role in China. Increased opportunities for communication in the world created a demand for oral proficiency in English (Black \& Cameron, 2002). Chinese public education system, however, seems not able to meet the spoken English learners' needs. This can be seen from the large number of the learners in English language training school who seek for what they really need there. This creates a big market for English Training Schools. Why do many college students prefer giving up the English class in public school which is compulsory and also much cheaper in tuition than English language training school? The teaching methods and techniques in Beijing English training schools are really worthwhile to research. According to Cook (2001), successful teaching results from learning; if students do not learn from the teaching, there is no benefit no matter how entertaining, lively, or well constructed the lessons are. What teaching methods the teacher employs in a specific class depends substantially on the practical realities of the classroom (Richards \& Rodgers, 2003). This research places focus on the teaching methods and skills on the SET (Spoken English Teaching) in BETS (Beijing English Training Schools) and aims to apply the theoretical and research prescriptions to practical spoken English teaching in order to enhance the effectiveness of SET in China.

\section{LITERATURE REVIEW}

\section{A. The Development of the Main TESL Teaching Methods}

In the TESL, one of the crucial decisions, if not the most important and challenging one, which each English teacher is confronted with is the choice of teaching methods and techniques (Cook 2001). Teaching method can be defined as the means by which theory is put into practice and choices made about the particular skills to be taught, the content will be asked and technique as "the level at which classroom procedures are described" (Richards \& Rodgers, 2003). According to Cutting (2007), the main differences between first-language acquisition and second or foreign language learning are whether the children or learners create their own structures; whether there is already a mother tongue present in their minds; and whether learning is affected by transfer from the L1 (first language). Because of the difference between L1 acquisition and L2 learning, SLA (Second Language Acquisition) teaching methods and approaches were produced to reflect various views on how non-mother-tongue language is best taught and learned (Yule, 2003). The SET in BETS is one part of L2 teaching. Therefore, to know the difference of various teaching methods is useful to instruct the SET in BETS.

Grammar Translation method was very popular in Europe and foreign language teaching from the mid- $19^{\text {th }}$ century to mid-20 th century. Until now, it is still widely used in some parts of the world (Richards and Rodgers 2003). In China, many college English teachers are used to teaching in Grammar-Translation Method, which is actually not suitable for spoken English teaching. In Grammar-Translation Method, the purpose of second language learning is to read literature written in it; Translating each language into another is an important goal; it emphasizes the reading and writing skills, not communicative skills; Learners are required to be aware of the grammatical rules of the target language (Freeman, 
2003). Therefore this method treats second or foreign language learning as an academic subject as any others (Yule, 2003). Audiolingual methodology uses Stimulus-Response-Reinforcement model to form good habits in language learners on the basis of behaviorist learning theory (Harmer, 2003) in the mid-1950s. Audiolingualism came from the incorporation of the linguistic principles of the Aural-Oral approach with state-of-the art psychological learning theory (Richards and Rodgers 2003). Littlewood (1990) claims that language learning is realized by imitation, reinforcement and repetition of behaviour. Mitchell and Myles (2002) strongly argue that language learning is the process of habit formation. The behaviorism theory behind Audiolingualism methodology was demonstrated in Fig. 1 (Richards and Rodgers 2003).

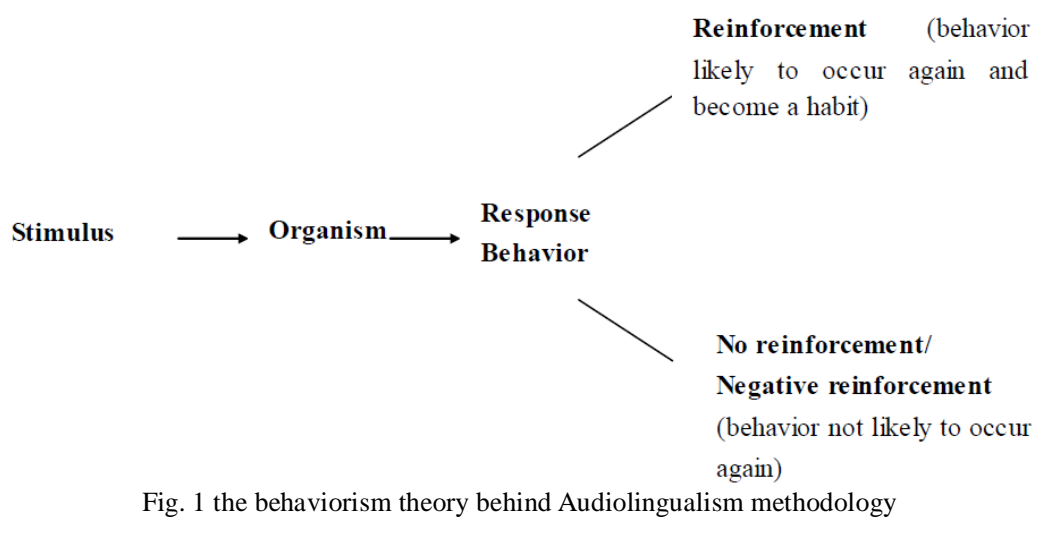

Audiolingualism methodology is a very important method in improvement the listening comprehension, accurate pronunciation (Brooks 1964), which are the essential abilities in spoken English learning. Therefore, Audiolingualism methodology is imperative to SET. However Audiolingualism methodology has a distinct drawback in that the isolated practice of drilling patterns is not same as the interactional nature of actual language use (Yule,2003). The Communicative approaches became popular in 1970s (McDonough \& Shaw, 2003). Hymes (1972) argued that the goal of language teaching was to develop 'communicative competence'. Wilkins (1976) claimed that communication required language learners to perform certain functions within a social context. All these opinions shift the language teaching from a linguistic structure-centered approach to a Communicative Approach (Widdowson, 1990). In contrast to Audiolingualism, communicative approaches emphasized both the functions of language as communication and the consciously learnt grammar of a language which would result in an ability to use the language (Yule, 2003). The main principles of communicative approaches put emphasis on communication, authentic and meaningful communication, fluency, and language skills (Richards \& Rodgers, 2003). Therefore, the language teaching is to be focused on communicative efficacy rather than on mere mastery of structures in order to develop 'communicative competence' (Richards \& Rodgers, 2003). Communicative approaches have significant influences to many other language teaching approaches and methods which "can be considered descendants of communicative language teaching" (Richards \& Rodgers, 2003, p.173).Thus, the communicative approaches are the most important approaches in SET.

\section{B. Teacher is the Key to Decide the Spoken English Teaching Approaches}

"Approaches and methods can be studied not as prescriptions for how to teach but a source of well-used practices, which teachers can adapt or implement based on their own needs." (Richards \& Rodgers, 2003, p.16), and "the teacher is the ultimate key to educational change and school improvement."(Hargreaves and Fullan, 1992, p.ix) That is to say, it is extremely difficult for BEST language teachers to come to conclusions about which approaches and methods are most appropriate for a certain teaching situation. Cook (2001) argues that "teaching methods usually incorporate a view of L2 learning", and knowing the needs of learners makes the teaching method more effective and much firmer. Thus, choosing the proper teaching methods according to the teaching and learning context is particularly important for successful teaching. To spoken English teachers, what teaching method they would choose to teach spoken English in the classroom has been an important issue. In the nineteenth century, a revolution in teaching was in putting the emphasis on the spoken language. Then a series of spoken language teaching methods appeared correspondingly, such as, the audio-lingual and audio-visual methods, communicative method, the Total Physical Response method, and so on. In the twentieth century, many linguists put emphasis on the importance of speech in that "speech is the primary form of language and writing depends on speech" (Cook, 2001, p.3-4).

\section{Methodology}

\section{A. Combination of Both Deductive and Inductive Methods.}

In this research the deductive approach is employed in the process of the identification of the spoken English teaching problems that Beijing English training schools faces. 8 spoken teachers as interviewees in BETS and 100 Chinese students as questionnaire respondents in BETS are directly involved in this research. Data collection concentrating on a limited number of samples may not be general, but it enables the spoken English teachers to gain 
in-depth understanding of specific cases. In the process of analysis, the employment of the inductive approach will be proved appropriate, as this research method will encourage exploration and explanation, which are central to this research.

\section{B. Combination of Both Quantitative and Qualitative Methods}

In order to increase the validity of information collected, both the academic and empirical research in this strategy will be used to provide different viewpoints. This research also presents the analysis of particular small-sized educational organization in BETS. The small sample means that the research is not likely to hold much external validity, which is typical for the statistical, quantitative research strategy. However, the research emphasizes the significance of the improvement of spoken English teaching and the importance of the useful teaching techniques they convey, which indicates that the study is of qualitative nature.

\section{DATAANALYSIS AND DisCUSSIONS}

From the data collected, the success of the SET in BETS depends to a great extent on the successful interlocking of various elements which influence the teaching directly. The understanding of the teaching environment appears to be crucial for teaching success. The awareness of the external and internal factors is indispensable for the needs-awareness SET in BETS. Furthermore, a well-designed teaching is paramount, as it determines whether the teaching is a success or failure.

In the learners' opinion on the allocation of the class time between teacher's talk and students' activities, $73 \%$ learners prefer more practice time for themselves in the class to teacher's long lecture in the spoken English class. This shows that the role of teachers should transfer from the knowledge giver, the controller and the authority to facilitator, organizer and participant of the class in SET in BETS, which is also the demand of 'learner-centered' teaching (Harmer, 2003). The learners' learning experiences and their response are at the center of a language course, and a good lesson should be mainly learners' activities, not the performance of the teacher (Harmer, 2003). Harmer (2003) said that all roles of teachers should aim to promote the learners' progress in some way or other, which are dependent on what the teachers wish the learners to achieve. In BETS, the aim of SET is to develop the learners' communicative abilities to express themselves and understand others. Therefore, the role of a spoken English teacher is clearly organizer, prompter and participant of the classroom activities.

According to the data, $70 \%$ of learners think their problems in spoken English learning are mixed, 11\% learners' problem is due to improper use of grammar, $8 \%$ learners' problem exists in bad understanding, $7 \%$ learners' problem is due to incorrect pronunciation, 4\% learners' only problem is caused by limited vocabulary. Therefore, the success of SET is built not only on the more interaction practice of the communicative abilities, but also the improvement of comprehension abilities, including grammar, listening understanding, pronunciation, and vocabulary. Mckay \& Tom (1999) point out that "language is an interrelated and meaningful whole" and the learners integrate every new bit of learning into an overall competence in a long process. Thus, all the factors of grammar, listening, pronunciation, and vocabulary are equally important and support each other. At the same time, spoken English teachers have to be good trainers in grammar, listening, pronunciation and vocabulary.

According to both interviews to 8 Spoken English teachers and questionnaires to the 100 spoken English learners in New Oriental School, one of the BETS, the spoken English teachers in BETS who choose to exploit a combination of different teaching methods to teach spoken English, which benefits language learning and teaching context, including the type of learners and the classroom situations. As mentioned above, the SET in BETS is learner-centered and need-awareness teaching. Learners' needs are the most essential factors to be considered by teachers. Thus, all the teaching methods, techniques and activities are based on this. According to the interview with teachers in BETS, learners are given the chance to express their expectations of the course by answering a questionnaire at the time of enrollment. This allows teachers to measure the different learners' ambitions and expectations against the content and methodology of the course which the teachers intend to organize.

According to the teachers' interviews, all the teachers agree that the SET in BETS is relatively learner-centered. Although the methods, techniques and activities employed in the teaching are varied, most teachers agree that whatever they are in SET, the improvement in students' communication abilities, interest evoking and learning determination attraction are the main aims of SET in BETS. In questionnaires to the students, most students think that the classes in BETS are always full of fun because of the totally humorous teaching style of all the teachers there. So they never feel bored with the classes. Besides this, the students think all the teachers there are very knowledgeable and they can learn a lot from them. Jeffcoate (1992) points out that the teacher ought to do everything within their power to get the learners to do more practice to get a good teaching result. Around learner-centered teaching, the main classroom activities of SET in BETS are role play and games, answering questions, group discussions and retelling, activities are no difference to other education systems. However, some teachers said that they did these activities with much enthusiasm and well-designed to make the activities more exciting and effective. They think if they want the learners to be enthusiastic and active in the classroom activities, the teachers themselves should be enthusiastic and active first, which will influence the learners to do more. Discussion and role play activities are agreed by all the teachers in BETS as good ways to develop the proficiency of spoken English. However, the teachers find that the learners in BETS may be unable 
or unwilling to participate in the discussion and role play classroom activities because of a variety of factors, such as linguistic limitations, educational practices and the failure of past learning, as well as different participant's different background and personality. Another reason is that, in China, the traditional English teaching method mainly refers to grammar-translation method. This teaching method makes students form the habit of keeping silent during much of the English class. Jaworski and Stephens (1998) suggested that silence in communication may be employed as a face-saving strategy. The use of silence, instead of verbal expression of critical views or disagreement, can be identified as the strategy of 'Don't do the FTA (face-threatening act)' (Nakane, 2006). Therefore, as the spoken English teachers design the classroom activities, they have to consider how to avoid the FTA as much as possible. For example, teachers have to decide when and how to correct students' language mistakes to avoid making students lose face.

According to the teachers' interviews, the spoken English teachers in BETS widely use modern technology to teach, such as computer-assisted language learning (CALL) tools, multi-media facilities and teaching software. A multi-media learning system offers the learner access to a range of real language situations, in which they can develop an increasing independence of action as their different social status allows. The advantages of the use of modern technology are obvious. According to Cook (2001), CALL has enhanced students' motivation, which reinforces the learning. CALL also provides a huge information database for learners. Stilborne and Heide (1996) said that the Internet provides learners with online texts, libraries, databases, news, travel, cooking, hobbies, and sports which enlarge the knowledge range of the learners' speech. And $80 \%$ of teaching information is stored in the world's computers (Graddol, 1997). The information technologies provide interactive multimedia presentations with sound, animation and full-motion video (Beatty, 2003). Weller (2002) points out it helps learners to reach a greater penetration in society than most other educational technologies.

\section{CONCLUSION}

The purpose of this research was to investigate the SET issues and find effective teaching methods in BETS. In the course of this research, after an introduction to the SET background in BETS, the academic literature on SET has been reviewed. It includes previous work done on the field of study and some issues considered to be relevant to the research questions and the investigation. It concludes with a brief review of the theories of second language teaching, the main skills and activities used in the SET, the choice of teaching methods and the relevant issues. If handled improperly, these issues can develop into serious barriers and impede the effectiveness and efficiency of the SET. To deal with these issues properly, the spoken English teachers have to consider all these aspects according to the specific teaching and learning context.

The SET in BETS study has suggested that the teaching context in BETS determines the teaching methods in SET. In a word, the nature of learner-centered and needs-awareness teaching determines all the aspects of the teaching in the particular teaching context. The author presents the findings on the relevant issues from both teachers' and learners' perspectives, which also give other teachers and curriculum developers some enlightenments on their own teaching or teaching programs.

\section{APPENDIX I QUESTIONS OF INTERVIEW (8 ENGLISH TEACHERS IN BEIJING NEW ORIENTAL SCHOOL)}

\section{QUESTIONS TO TEACHERS OF SPOKEN ENGLISH TEACHING IN BEIJING ENGLISH TRAINING SCHOOLS \\ BACKGROUND INFORMATION}

Purpose of the study:

These questions are being conducted for the study on Spoken English Teaching in Beijing English Training Schools.

The goal of these questions is to map the understanding and views of teachers on Spoken English training classes. This interview will take 30 minutes.

Interview questions:

1. Do you think spoken English Training course in English Training schools in Beijing is a good supplement for the English Teaching in formal Schools? Why?

2. How do you deal with spoken English teaching in the situation of big class size, different age learners with different English levels?

3. What are the aims of students who take part in the spoken English training in English training schools in Beijing?

4. Do you agree with the idea that the English teaching is totally learner-centered in English training schools in Beijing? If you agree, what kind of teaching method do you use in your spoken English teaching? And why?

5. How do you make spoken English teaching more purposeful to different student groups?

6. By what techniques, methods and activities, do you think, you teach the spoken language? And why?

7. What technology do you use to teach the spoken language to your students? Why?

APPENDIX II: QUESTIONNAIRE FOR STUDENTS

\section{BACKGROUND INFORMATION}

Purpose of the study: 
This questionnaire is being conducted for the study on Spoken English Teaching in Beijing English Training Schools. The goal of this questionnaire is to map the understanding and views of students on Spoken English training classes. This questionnaire will take 10 minutes to complete.
1. Sex: (please tick)
2. Age:
3. Status:
4. Major:
5. Spoken English Level$$
\text { Female } \square
$$
Student $\square$
Male $\square$
SPOKEN ENGLISH TEACHING QUESTIONS FOR STUDENTS

1. In spoken English classes, what is the allocation of the class time you would prefer?

a. 30\% teacher's speech, $70 \%$ students' practice or communication in English

b. $70 \%$ teacher's speech, $30 \%$ students' practice or communication in English

c. $50 \%$ teacher's speech, $50 \%$ students' practice or communication in English

d. others : (please give a brief description)

2. Which one, do you think, is the most useful element to learn spoken English well?

a. large vocabulary

b. good grammar

c. imitate and repeat correct sentence structure

d. good listening ability

e. good at conversations

f. good at communication

g. good at doing role plays

h. all of the above

i. other elements: (please give a brief description)

3. Which oral English learning method do you prefer in your spoken English training?

a. I prefer to do listening and speaking practices in the classes as much as possible.

b. I always take notes of the spoken English language points and usages and listen to the teachers' lecture. In this way, I feel safe in the class.

c. Real world situations, such as films, with the teacher's occasional instructions make you feel like you are emerging in the real English language environment.

d. I prefer to do a lot of interpretation exercises in the training classes

e. other ways: ( please give a brief description)

4. What do you think attracts your attention most in the spoken English classes?

a. The teacher accelerates the speed of the his speech

b. The teacher excites you by some humorous speech or anecdotes.

c. The teacher raises his voice

d. The teacher is very humorous

e. The teacher is very knowledgeable

f. The teacher plays English games

g. all of the above

h. other ways: ( please give a brief description)

5. Which spoken teaching methods, do you think, are applied in the spoken English training school class?

a. Vocabulary and grammar-rules are the centre of the teaching (grammar-translation method)

b. No L1 was involved; speech and listening comprehension were taught; correct pronunciation and grammar were emphasized (Direct Method)

c. learn spoken English sentence by sentence through imitation and memorization (Audio-lingual Method)

d. Communication is the center of the teaching (Communicative approaches)

e. other methods: (please give a brief description)

6. Which classroom activity, do you think, are used frequently in the spoken English training school class?
a. role play
b. intonation gap activities
c. group discussion
d .learning spoken English by films
e. tell or retell the stories
f. small presentation
g. small oral report
h. answer questions
i. all of the above
j. other activities (please give a brief description)

7. In spoken English classes, do you want your spoken teacher to interrupt your speech and correct your 
pronunciation every time when you make a mistake?

a. No. It will make me frustrated. I can correct pronunciation by imitating English tapes.

b. No. I will forget what I want to say.

c. Yes. But I hope it happens at the end of my speech.

d. Yes. Every time I make pronunciation mistakes, the teacher should correct me.

\section{REFERENCES}

[1] Beatty, K. (2003). Teaching and Researching Computer-Assisted Language Learning. London: Longman.

[2] Black, D \& D, Cameron (2002). Globalization and Language Teaching. Great Britain: Routledge.

[3] Brooks, N. (1964). Language and language learning: Theory and Practise. $2^{\text {nd }}$ ed. New York: Harcourt Brace.

[4] Cook, V (2001). Second Language Learning and Language Teaching (Third Edition). Oxford: Oxford University Press.

[5] Cutting, J. (2007). Linguistics for Teachers. Sunderland: University of Sunderland.

[6] Freeman, L. D. (2003). Techniques and Principles in Language Teaching (6 ${ }^{\text {th }}$ edition). Oxford: Oxford University Press.

[7] Graddol, D. (1997). The Future of English? London: The British Council.

[8] Hargreaves, A., \& Fullan, M. G. (Eds.). (1992). Understanding teacher development. New York: Teachers College Press.

[9] Harmer, J. (2003). The Practise of English Language Teaching. Pearson Education Limited Pp. 37, 53-57

[10] Hymes, D. (1972). On communicative competence. In: J. C. Richards \& T. S. Rodgers (2003) Approaches and Methods in Language Teaching (Second edition), pp.159. Cambridge University Press.

[11] Jaworski, Adam and Dafydd, Stephens. (1998). Self-reports on silence as a face-saving strategy by people with hearing impairment. International Journal of Applied Linguistics. 8 (1). Pp.61-80.

[12] Jeffcoate, R. (1992). Starting English teaching. Great Britain: Routledge publication.

[13] Littlewood, W. (1990) Foreign and Second Language Learning. Cambridge: Cambridge University Press.

[14] McDonough, J. \& Shaw, C. (2003). Materials and Methods in ELT: a Teachers' Guide. Oxford: Blackwell Publishing.

[15] Mckay, H. \& A. Tom. (1999). Teaching Adult Second Language Learners. The United Kingdom: Cambridge University Press.

[16] Mitchell, R. \& Myles, F. (2002). Second Language Learning Theories. London: Arnold

[17] Nakane, Ikuko. (2006). Silence and politeness in intercultural communication in university seminars. [online] In: Journal of Pragmatics. 38 (11). Pp.1811-1835. Available form: www.sciencedirect. com/science/journal/03782166. (access 02/02/2008).

[18] Richards, J. C. \& Rodgers, T. S. (2003). Approaches and Methods in Language Teaching (Second edition). Cambridge: Cambridge University Press.

[19] Stilborne, L. \& Heide, A. (1996). The Teacher's complete and easy Guide to the Internet. Ontario: Trifolium Books Inc.

[20] Weller, M. (2002). Delivering Learning on the Net: the why, what \& how of online education. USA: Stylus Publishing Inc.

[21] Widdowson, H. G. (1990). Aspects of Language Teaching. Oxford: Oxford University Press. In: Freeman, L. D. (2003) Techniques and Principles in Language Teaching (6 ${ }^{\text {th }}$ edition). Oxford: Oxford University Press.

[22] Wilkins, David A. (1976). Notional Syllabuses. Oxford: Oxford University Press. In: Freeman, L. D. (2003) Techniques and Principles in Language Teaching (6 ${ }^{\text {th }}$ edition). Oxford: Oxford University Press.

[23] Yule, G. (2003). The Study of Language (Second Edition). Cambridge: Cambridge University Press.

Weihong Li was born in Huhhot, Inner Mongolia, China in 1973. She received her MA degree in TESOL from Sunderland University, Britain in 2008. She is currently a lecturer in the Foreign Language Department, Beijing Information Science University, Beijing, China. Her academic research mainly focuses on applied linguistics and L2 teaching.

Xuedong Shi was born in Huhhot, Inner Mongolia, China in 1974. He received his MA degree in translation in Middlesex University, Britain, in 2004. He is currently a lecturer in the Foreign Language Department, Beijing Information Science University, Beijing, China. His academic research mainly focuses on translation and applied linguistics. 